\title{
Wage rigidity and employment adjustment at the firm level: Evidence from survey data*
}

\author{
Daniel A. Dias ${ }^{\dagger}$ Carlos Robalo Marquesł and Fernando Martins ${ }^{\ddagger}$
}

\begin{abstract}
This paper uses firm level survey data from Portugal to investigate how firms adjust their labour costs in the presence of wage rigidities. We document that Portuguese firms, besides reducing employment or freezing nominal base wages, also make frequent use of other cost-cutting strategies, like freezing or cutting bonus and other monetary or non-monetary benefits, slowing down or freezing the rate at which promotions are filled, or recruiting new employees at wages lower than those received by the employees that have left the firm. We show that the utilization of these different adjustment strategies is affected by workers' and firms' attributes, as well as by some indicators of the economic environment in which firms operate. More importantly, we provide evidence that firms with more flexible base wages are less likely to reduce employment, and that such effect may be significantly strengthened by the availability of alternative labourcost adjustment margins that firms can use in bad times.
\end{abstract}

JEL classification: J32, J62, C35

Key words: Wage rigidity, non-wage labour costs, unemployment, probit model.

${ }^{*}$ We would like to thank Claudia Duarte and Pedro Portugal for helpful discussions and useful suggestions. Any errors or omissions are the sole responsibility of the authors.

${ }^{\dagger}$ Department of Economics, University of Illinois at Urbana-Champaign and CEMAPRE. Email: ddias@illinois.edu

¥Banco de Portugal (Research Department).E-mail address: cmrmarques@bportugal.pt

${ }^{\S}$ Banco de Portugal (Research Department), ISEG (Technical University of Lisbon) and Universidade Lusíada de Lisboa. E-mail address: fmartins@bportugal.pt 


\section{Introduction}

Understanding the interaction between wage and employment adjustments is very important for the design of monetary or fiscal policies aiming to stabilise the economy. This paper contributes to this literature by analysing how firms, in the presence of wage rigidity, combine different channels of labour-cost adjustment in response to adverse shocks.

Wage rigidity is expected to have implications for unemployment because, in the face of negative shocks, employment adjustment is likely to be larger when wages are rigid downwards. Wage rigidity is also thought to have important implications for monetary policy, as it may condition the inflation target that monetary authorities should pursue. If nominal wages were perfectly flexible it would be optimal to aim at zero inflation but, in the presence of downward nominal wage rigidity, a certain amount of inflation may be required to "grease the wheels" of the labour market by easing reductions in real wages. ${ }^{1}$

The bulk of the empirical literature aimed at assessing the extent and the effects of nominal wage rigidities has focused on base wages or permanent wages (base wages plus other components that are paid on a permanent or regular basis, such as meals allowances, tenure-related components, etc.), leaving aside potentially more flexible pay components, such as performance-related bonuses, commissions and other benefits, which may strongly attenuate the negative impact on employment of strict downward base-wage rigidity. ${ }^{2}$ Exceptions are the contributions by Lebow et al. (2003), Dwyer (2003) and Oyer (2005) who look at the role played by benefits in reducing nominal wage rigidity. They conclude that firms seem to be able to partly circumvent wage rigidity by varying benefits so that total compensation displays less rigidity than do

\footnotetext{
${ }^{1}$ For a discussion, see, among many others, Akerlof et al. (1996), Gordon (1996), Mankiw (1996), Dwyer (2003), Fehr and Goette (2005), Carlsson and Westermark (2007), Elsby (2009), Messina and Sanz-de Galdeano (2011) and Stüber and Beissinger (2012).

${ }^{2}$ For empirical evidence on downward wage rigidity see, for instance, Altonji and Devereux (2000), Knoppik and Beissinger (2006), Dickens et al. (2007), Goette et al. (2007), Holden and Wulfsberg (2008, 2009), Behr and Pötter 2010) and Messina et al. (2010).
} 
wages alone.

This paper extends the existing literature by discussing the implications of wage rigidity in a context where several labour-cost adjustment margins are available to firms. Since firms are primarily concerned with total compensation per employee, the assessment of the importance of these alternative labour cost adjustment strategies is crucial to evaluate the overall degree of labour cost flexibility and its implications. Based on firm-level survey data for a sample of Portuguese firms, this paper investigates whether these alternative margins of labour cost adjustment have been used as substitutes or complements to base wages and, most importantly, whether their utilisation has significantly reduced the detrimental impact on employment of base-wage rigidities in the Portuguese labour market.

From our dataset we observe that, among the firms that have cut labour costs, the reduction in the number of employees ("reduce employees") was by far the most commonly used strategy (around 72 percent of the firms), followed by the use of "flexible margins", which include the reduction or elimination of bonus payments and other monetary and non-monetary benefits and the slowdown or freezing of the rate at which promotions are filled (around 45 percent of the firms). The recruitment of new employees with a wage lower than the one of those who left the firm ("cheaper hires") was used by around 30 percent of the firms and, finally, around 26 percent of the firms have frozen base wages ("base-wage freezes"). The use of the different labour cost-cutting strategies does not seem to vary much across sectors or firm sizes.

From the estimated model, we find that the use of each strategy is related to several workers' and/or firms' attributes such as the tenure and skill distribution, to some measures of the unions' bargaining power, as well as to some indicators of the economic environment in which they operate. Firms operating in foreign markets, which typically face a more competitive environment, tend to use some of these strategies more heavily.

The estimated results suggest that the strategy "cheaper hires" is used a substitute for "base-wage freezes", i.e., it is mainly used in situations in which firms do not 
freeze base wages after a negative labour demand shock or to compensate abnormal or unexpected base-wage increases after a negative labour supply shock. In contrast, the relationship between the strategies "flexible margins" and "base-wage freezes" is positive (even though not significantly so), which suggests that the reduction or elimination of bonuses and other benefits is predominantly used as a complement to "base-wage freezes" in reaction to negative labour demand shocks.

We also find a clear negative association between the margin "base-wage freezes", which we interpret as a measure of base-wage flexibility, and the margin "reduce employees". We estimate that the probability of a firm reducing employment is around 21 percentage points lower for a firm that has frozen base wages than for an otherwise identical firm. The ability to use either the "flexible margins" or the "cheaper hires" decreases the probability of a firm reducing employment (around 6.5 percentage points in each case). Together, for a firm that uses the strategies "base-wage freezes", "flexible margins" and "cheaper hires", the probability of reducing employment is around 35 percentage points lower than for an otherwise identical firm.

These results show that wage flexibility is likely to have a strong positive impact on employment in the face of negative labour supply and demand shocks, and that such positive impact is significantly reinforced by the existence of alternative margins of labour cost adjustment. In particular, the availability of compensation components (bonus, benefits and promotions) that firms can freeze or cut in bad times, and the possibility of recruiting new employees at a wage lower than the one of those who have recently left the firm have certainly contributed to partly offset the negative impact of base-wage rigidities on employment.

The rest of the paper is organised as follows. Section 2 describes the dataset. Section 3 provides the institutional and theoretical background for the econometric model used in the empirical section of the paper. Section 4 presents some preliminary analysis of the data. Section 5 discusses the econometric methodology, presents the estimated models and discusses the main results. Section 6 provides some concluding 
remarks. Finally, the Appendix describes how the different variables were constructed.

\section{Data sources}

Most of the data used in this study come from a survey on wage and price setting practices carried out by Banco de Portugal in 2008 on a sample of Portuguese firms ${ }^{3}$.

In this survey, firms were asked two questions pertaining to the different margins of labour cost adjustments, including base-wage freezes, reduction or elimination of other compensation components and reduction of employment.

As regards base-wage freezes firms were asked the following question: "Over the last five years, has the base wage of some workers in your firm ever been frozen?". Under the assumption of a common negative shock, and in the absence of nominal wage cuts, wage freezes identify those firms in the sample where base wages exhibit the lowest degree of real downward rigidity. Thus, for the purposes of the present paper, we look at base-wage freezes as a measure of downward wage flexibility. ${ }^{4}$

In the second question, firms were asked if they had ever used ways of cutting labour costs other than changing their base wages. In particular, they were asked the following question: "Have you ever used any of the following strategies to reduce labour costs?" Firms participating in the survey were allowed to choose as many options as they wished from the list below:

1) Reduce or eliminate bonus payments and other monetary benefits;

2) Reduce or eliminate non-monetary benefits;

3) Slow or freeze the rate at which promotions are filled.

4) Recruit new employees at a wage lower than the one of those who left the firm;

\footnotetext{
${ }^{3}$ Details on the sample selection method, as well as a copy of the full questionnaire can be found in Martins (2011).

${ }^{4}$ Information on wage freezes has been used in the literature as a measure of the degree of downward nominal wage rigidity (see, for instance, Babecký et al. $(2009,2010)$ ). In our view, however, wage freezes can be seen as a measure of downward nominal wage rigidity only if the analysis is restricted to the population of firms where wages have been frozen or cut (see for instance, Holden (2004), Dickens et al. (2007) and Holden and Wulfsberg (2008)). Radowski and Bonin (2008) have also used the frequency of wage freezes or wage cuts as a proxy for wage flexibility in Germany.
} 
5) Reduce the number of employees.

These five strategies together with wage freezes summarise the main labour costcutting strategies available to Portuguese firms in the face of negative shocks. ${ }^{5}$ Wage freezes and strategies 1 to 4 may be seen as affecting the average price of labour. Further below, for estimation purposes and tractability reasons, strategies 1 to 3 (the reduction or elimination of monetary and non-monetary benefits and the slowdown or freezing of promotions) will be aggregated in a single margin and denoted together as "flexible margins" as they are usually seen as more flexible than base wages. The reduction in the number of employees affects the quantity of labour and will be denoted simply as "reduce employees".

Besides the questions on base-wage freezes and on the alternative margins of labour cost reduction, the survey also contains information on a large set of firms' characteristics. These include information on the composition of the labour force (share of white collar vs. blue collar workers; share of low skilled vs. high skilled workers; share of workers with permanent contracts), the percentage of workers covered by collective wage agreements, the share of exports in firms' total sales, and the relevance of some factors as obstacles to wage cuts/freezes in a context where firms may desire to reduce their labour costs, such as the constraints imposed by collective wage agreements, the negative impact on firms' reputation or the difficulties in attracting new workers in the future.

After excluding from the sample those firms that have not fully answered the two questions on the alternative strategies to reduce labour costs, we were able to obtain detailed information on 1319 firms from different branches of activity. More specifically, our sample includes firms with 10 or more employees, covering manufacturing (38

\footnotetext{
${ }^{5}$ The original question in the survey included also the option "Change the policy of shifts (reducing the number of hours and or shift premia)". The answers to this option are not analised in the paper because they involved a small number of firms and because we also believe that such option is basically used by firms whose product has very specific characteristics, making it difficult to find a meaningful set of regressors capable of explaining why some firms use that option with higher probability than others.
} 
percent), energy (3 percent), construction (11 percent), retail and wholesale trade (17 percent), and other business services (31 percent).

However, for estimation purposes, and for reasons that will become clear further below, we restrict the analysis to firms that have reduced costs, i.e., that have used at least one cost-cutting strategy. This reduces the original sample to 757 firms. Also for estimation purposes, the information from the survey was supplemented with data from Quadros de Pessoal, a large administrative database collected by the Ministry of Employment and Social Security, which, among other, includes information about all the Portuguese firms with wage earners (size, ownership, location, etc.). From this database, we obtained information on size (number of employees) and workers' tenure.

By combining these two datasets through the individual tax identification number of each firm and after excluding the firms that have not answered to all the questions that are used as regressors in the estimated model the initial sample is reduced to 635 firms. This constitutes the final sample retained for estimation purposes.

\section{Institutional and theoretical background}

\subsection{Institutional background}

In the face of negative labour demand or supply shocks, firms are expected to reduce labour costs. This can be achieved by reducing employment and/or the average labour costs. In the real economy, however, firms face restrictions in terms of the channels of adjustment they can use, so that the way in which they distribute shocks across the various labour-cost adjustment channels is expected to depend not only on the technological and market restrictions, but also on the institutional and structural constraints of the economy, including wage rigidity and employment protection legislation.

As regards nominal wage rigidity, many studies place the Portuguese labour market among the most rigid countries in Europe (see, Behr and Pötter (2010), Messina et al. (2010), Holden and Wulfsberg (2008), Dickens et al. (2007) and Knoppik and 
Beissinger (2006)). Such rigidity stems above all from the fact that labour legislation forbids nominal wage cuts. According to the Portuguese law, a firm cannot reduce contracted wages, including other regular and periodic monetary or non-monetary pay components, unless this is permitted by collective agreements. As a general rule, only bonus, commissions and other monetary or non-monetary benefits associated to the worker's performance, not included in the collective agreement, may legally be reduced (Portuguese Labour Code, art. 129, 258 and 260). Also, collective negotiations are usually conducted at the industry or occupation level, and collective agreements stipulate minimum working conditions, like the monthly minimum wage for each category of workers, overtime pay and the normal duration of work. Such collective bargaining covers a large part of the workforce resulting both from the presence of labour unions and the existence of mechanisms of contract extension, i.e., the Government normally uses extension mechanisms to broaden the coverage of the collective bargaining agreement to workers not covered by unions. This largely regulated institutional framework, as well as the existence of a compulsory minimum wage, which establishes a wage floor for many workers, introduce strong additional rigidity in the wage-setting process. ${ }^{6}$

In contrast, the Portuguese labour market is usually seen as displaying a very low level of real wage rigidity. This conclusion emerges not only from the literature that investigates the degree of real wage rigidity from micro data by computing measures of downward real wage rigidity from the distribution of wages changes (see Dickens et al. (2007) and Messina et al. (2010)), but also from the literature that looks at the wage supply curve using micro or macro data, where real wages appear as highly responsive to the unemployment rate (see OECD (1992), Luz and Pinheiro (1993), Gaspar and Luz (1997), Dias et al. (2004) and Marques (2008)). Estimates based on more recent data, however, suggest that things may have changed significantly during the last decade or so. According to Portugal et al. (2010), the large cyclical sensitivity

\footnotetext{
${ }^{6}$ In recent years, however, the number of firm-level agreements, which are supposed to allow greater wage flexibility, has increased. According to our survey, they are present in around 10 percent of the firms.
} 
of real wages, prevailing in the 1980s and the 1990s, has basically vanished in the most recent period. ${ }^{7}$

The Portuguese labour market is also seen as displaying a high level of employment rigidity among European economies mainly due to legislation that protects employees with permanent contracts against individual dismissal (see Venn $(2009))$. Nevertheless, the typical Portuguese firm appears to have more control over employment than it has over contracted wages, namely because it has the possibility of resorting to collective dismissals and temporary contracts or finding ways to get around individual dismissals regulation by negotiating voluntary quits.

\subsection{Theoretical background}

Given the characteristics of the Portuguese labour market, we assume a "right to manage" situation where base wages are bargained collectively but other components of total compensation and employment are chosen optimally by firms subject to adjustment costs (namely hiring and firing costs), as well as to institutional constraints.

In order to discuss the impact of negative labour demand and supply shocks on wages and employment, we start with a very stylised model where it is assumed that firms do not pay bonuses or any other monetary or non-monetary benefits, so that total compensation coincides with base wages. To maximise profits in a "right to manage" situation firms must choose employment so as to equate the wage, which they take as given, to labour's marginal impact on firm's revenues. Let us assume that the inverse labour demand schedule of firm $i$ may be written as:

$$
w_{i}=-\theta_{i} l_{i}+d_{i}
$$

where $w$ is the $\log$ of firm's labour cost, $l_{i}$ is the log of employment, $d_{i}$ measures

\footnotetext{
${ }^{7}$ According to the authors' estimates, the semi-elasticity of real wages to changes in the unemployment rate dropped from -2.46 in the $1986-2000$ period to about zero in the 2002-2007 period for job-stayers, and from -0.955 to -0.343 for new-hires.
} 
other factors that affect labour demand (marginal revenues) and $\theta_{i}$ is the inverse of the elasticity of the labour demand schedule.

Similarly, let us assume that firm $i$ faces the following inverse log-linear labour supply schedule:

$$
w_{i}=\lambda_{i} l_{i}+s_{i}
$$

where $\lambda_{i}$ is the inverse of labour supply elasticity and $s_{i}$ measures other factors that affect labour supply. Solving the two equations for wages and employment, we get:

$$
\begin{aligned}
w_{i} & =\frac{\theta_{i}}{\lambda_{i}+\theta_{i}} s_{i}+\frac{\lambda_{i}}{\lambda_{i}+\theta_{i}} d_{i} \\
l_{i} & =\frac{1}{\lambda_{i}+\theta_{i}}\left(d_{i}-s_{i}\right)
\end{aligned}
$$

In this simple framework, a labour demand shock may be represented by $\Delta d_{i}$. Labour demand shocks may reflect technological shocks, fluctuations in the price of factors other than labour (e.g., energy) or output demand shocks. The equilibrium wage and employment reactions to labour demand shocks are given by:

$$
\begin{aligned}
\Delta w_{i} & =\frac{\lambda_{i}}{\lambda_{i}+\theta_{i}} \Delta d_{i} \\
\Delta l_{i} & =\frac{1}{\lambda_{i}+\theta_{i}} \Delta d_{i}
\end{aligned}
$$

Since the elasticity of labour demand depends on the the degree of decreasing returns to labour, on labour's substitutability with other factors of production and on the elasticity of product demand (see Hamermesh (1987)), all these features affect the reaction of employment to shocks. The response of employment to labour demand shocks is small when the labour supply curve is inelastic, i.e., $\lambda_{i}$ is large. In contrast, if wages do not change, i.e., $\lambda_{i}$ is very small, possibly because they are set by binding collective wage agreements, then employment responds strongly to labour demand shocks. 
In a dynamic context, however, wages and employment need not vary along the static labour demand curve. Employment protection legislation can smooth employment dynamics in the face of shocks, so that employment fluctuations are expected to be less frequent and also less pronounced on average (see Bertola (1999)). The ability of wages to respond to firm-level and common shocks also depends on institutional features, as well as on local labour market conditions, especially when labour mobility is low (see Topel (1986)).

Thus, in the face of a negative labour demand shock several final adjustments are possible. If the firm is not able to freeze nominal wages (the most likely situation under downward wage rigidity), it will likely reduce employment and answer in the survey that it has reduced employment but not frozen wages. If, by negotiating with the workers' representatives, the firm manages to freeze nominal wages (the best it can aim at, given the existence of strict base-wage nominal downward rigidity), the firm will answer in the survey that it has frozen wages and reduced employment (if freezing wages was not enough to prevent employment reduction) or that it has frozen wages and not reduced employment, otherwise.

Let us now consider a wage shock which we represent by $\Delta s_{i}$. The employment impact of such shock is given by:

$$
\Delta l_{i}=\frac{-1}{\lambda_{i}+\theta_{i}} \Delta s_{i}
$$

Thus, employment responses are expected to be larger when $\theta_{i}$ is small, i.e., labour demand is more elastic, which in turn reflects the degree of market competition, as well as the substitutability of labour with other factors. In the face of a negative labour supply shock (for instance, an unexpected base-wage increase imposed by collective agreements), the most likely final outcome (in the absence of other adjustment mechanisms) is a reduction in employment, so that the firm will answer in the survey that it has reduced employment but has not frozen wages. 
Summing up, the cases in which firms have reacted by freezing base wages (reducing or not employment at the same time) are responses to a negative labour demand shock. The cases in which firms have reduced employment but have not frozen base wages may be the reaction either to a negative labour demand or to a negative labour supply shock.

The role played by the alternative mechanisms investigated in this paper, like the flexible components of total compensation (such as bonus and other monetary and non-monetary benefits) and the possibility of recruiting new employees at a lower wage than the one of those who have left the firm, may be discussed by noting that they operate in the model by affecting total compensation and thus the labour supply and demand curves. In the context of downwardly rigid base wages, the negative impact on employment of a negative labour demand shock will be lower if the firm has the possibility of resorting to other total compensation components (i.e., freezing or reducing bonuses and other monetary or non-monetary benefits, freezing or slowing down the rate at which promotions are filled or recruiting new employees at wages lower than those received by the employees that have recently quit). Similarly, in the face of a negative labour supply shock, these margins may be used to attenuate the increase in total compensation, reducing the negative impact on employment. In the case of a negative labour demand shock, these margins will emerge in the sample either as complements to base-wage freezes (if firms manage to freeze wages), or as substitutes (if firms are unable to freeze base wages) while, in the case of a negative supply shock, they will emerge as substitutes to (unexpected) base-wage increases.

\section{Preliminary data analysis}

Table 1 summarises some information on the different cost-cutting strategies used by Portuguese firms in our sample. From the table, we see that the reduction in the number of employees ("reduce employees") is by far the most used strategy. Indeed, around 72 percent of the firms in the sample answered that they had used this margin 
in the past. The "flexible margins", which aggregates the reduction or elimination of bonus payments and other monetary benefits ("reduce bonus"), the reduction or elimination of non-monetary benefits ("reduce benefits") and the slowdown or freezing of promotions ("slowdown promotions"), ranks second with around 45 percent of the firms, and the recruitment of new employees with a wage lower than the one of those who left the firm ("cheaper hires") ranks third with around 30 percent of the firms.

Table 1: Labour cost-cutting strategies

(Share of firms that have used each margin at least once)

\begin{tabular}{|c|c|c|c|c|c|c|c|}
\hline \multirow[b]{2}{*}{$\begin{array}{l}\text { Sectors and firm } \\
\text { sizes }\end{array}$} & \multirow{2}{*}{$\begin{array}{c}\text { Base } \\
\text { wage } \\
\text { freezes }\end{array}$} & \multicolumn{3}{|c|}{ Flexible wage margins } & \multirow[b]{2}{*}{$\begin{array}{l}\text { Flexible } \\
\text { margins }\end{array}$} & \multirow[b]{2}{*}{$\begin{array}{l}\text { Cheaper } \\
\text { hires }\end{array}$} & \multirow[b]{2}{*}{$\begin{array}{c}\text { Reduce } \\
\text { employees }\end{array}$} \\
\hline & & $\begin{array}{l}\text { Reduce } \\
\text { bonuses }\end{array}$ & $\begin{array}{l}\text { Reduce } \\
\text { benefits }\end{array}$ & $\begin{array}{c}\text { Slow } \\
\text { promotions }\end{array}$ & & & \\
\hline Total & 0.258 & 0.243 & 0.148 & 0.246 & 0.454 & 0.297 & 0.715 \\
\hline Manufacturing & 0.284 & 0.254 & 0.167 & 0.227 & 0.448 & 0.284 & 0.732 \\
\hline Energy & 0.190 & 0.190 & 0.095 & 0.238 & 0.333 & 0.333 & 0.857 \\
\hline Construction & 0.254 & 0.127 & 0.127 & 0.282 & 0.423 & 0.282 & 0.803 \\
\hline Trade & 0.252 & 0.289 & 0.111 & 0.163 & 0.422 & 0.274 & 0.681 \\
\hline Business services & 0.254 & 0.221 & 0.136 & 0.296 & 0.479 & 0.315 & 0.690 \\
\hline Large firms & 0.244 & 0.269 & 0.154 & 0.260 & 0.474 & 0.349 & 0.724 \\
\hline Small firms & 0.276 & 0.208 & 0.140 & 0.227 & 0.429 & 0.277 & 0.702 \\
\hline
\end{tabular}

Note: "Flexible margins" is the aggregation of "reduce bonus", "reduce benefits" and "slow promotions". Large firms are those firms with 100 or more employees, while firms with less than 100 employees are considered as small firms. Number of observations: 757 .

Table 1 also shows that the use of the different strategies by Portuguese firms does not vary much across sectors, with the possible exception of energy and construction. The energy sector displays a slightly lower usage of "base-wage freezes" and "flexible margins" and a relatively higher usage of "cheaper hires" and "reduce employees", while firms in the construction sector also use the "reduce employees" strategy more frequently than the average firm.

As regards the distribution by firm size, Table 1 does not reveal strong asymmetries. Nevertheless, large firms seem more likely to use the "flexible margins" and "cheaper hires", as opposed to small firms which seem to make a more extensive use of "basewage freezes".

According to the discussion in Section 3, we may expect the detrimental implications for employment of base-wage rigidity to be partly offset by the availability of other 
mechanisms through which firms can reduce their labour costs, such as the "flexible margins" and/or the "cheaper hires". In order to investigate whether some of these relationships are apparent in the data, we computed some sample conditional proportions, as well as tetrachoric correlation coefficients for pairings of different margins (see Tables 2 and 3, respectively).

Table 2: Sample conditional proportions

\begin{tabular}{|l|c|c|c|c|}
\hline \hline & $\begin{array}{c}\text { Reduce } \\
\text { employees }\end{array}$ & $\begin{array}{c}\text { Cheaper } \\
\text { hires }\end{array}$ & $\begin{array}{c}\text { Flexible } \\
\text { margins }\end{array}$ & $\begin{array}{c}\text { Base-wage } \\
\text { freezes }\end{array}$ \\
\hline \hline $\mathrm{P}()$. & 0.715 & 0.297 & 0.454 & 0.258 \\
\hline $\mathrm{P}(. \mid$ Base-wage freezes=1) & 0.564 & 0.215 & 0.503 & 1 \\
\hline $\mathrm{P}(. \mid$ Flexible margins=1) & 0.657 & 0.305 & 1 & - \\
\hline $\mathrm{P}(. \mid$ Cheaper hires=1) & 0.680 & 1 & - & - \\
\hline \hline
\end{tabular}

$\mathrm{P}(\mathrm{Y} \mid \mathrm{X}=1)$ stands for the proportion of firms that used strategy $\mathrm{Y}$ among those firms that have used strategy X. Number of observations: 757 .

Table 3: Tetrachoric correlation coefficients between different pairs of labour cost-cutting strategies ${ }^{(a)}$

\begin{tabular}{|l|c|c|c|c|}
\hline \hline & $\begin{array}{c}\text { Reduce } \\
\text { employees }\end{array}$ & $\begin{array}{c}\text { Cheaper } \\
\text { hires }\end{array}$ & $\begin{array}{c}\text { Flexible } \\
\text { margins }\end{array}$ & $\begin{array}{c}\text { Base-wage } \\
\text { freezes }\end{array}$ \\
\hline \hline Base-wage freezes & $-0.330^{* * *}$ & $-0.195^{* * *}$ & 0.097 & 1.000 \\
\hline Flexible margins & $-0.193^{* * *}$ & 0.027 & 1.000 & \\
\hline Cheaper hires & -0.086 & 1.000 & & \\
\hline Reduce employees & 1.000 & & & \\
\hline
\end{tabular}

(a) ${ }^{* * *},{ }^{* *}$ and ${ }^{*}$ stand for significance at 1,5 and 10 percent level, respectively; Number of observations: 757 .

From Table 2, we see that around 72 percent of the firms in the sample have reduced employment but only around 26 percent have frozen wages, which suggests that a large proportion of firms has reduced employment without freezing wages. However, among the firms that have frozen base wages only around 56 percent have also reduced employment. In turn, from Table 3, we see that the correlation coefficient between "base-wage freezes" and "reduce employees" is significantly negative (-0.330). Thus, 
overall, the sample evidence suggests that "base-wage freezes" might have been used as a substitute to employment reduction.

A similar picture emerges for "cheaper hires". Conditional on having frozen wages, only around 22 percent of the firms have used "cheaper hires", compared to around 30 percent in the full sample. The correlation between "base-wage freezes" and "cheaper hires" is also significantly negative $(-0.195)$.

In contrast, there is no indication that "flexible margins" could have been used as a substitute for "base-wage freezes". If anything, the data suggest that firms that managed to freeze wages also tended to use the "flexible margins". In other words, flexibility in the total compensation components ("base-wage freezes" and "flexible margins") seems to be positively correlated, even though not significantly so (Table 3).

As regards the other strategies, Table 2 suggests that "flexible margins" or "cheaper hires" could also have been used as substitutes to employment reduction, but according to Table 3 only the correlation between "flexible margins" and "reduce employees" appears as significantly different from zero. Finally, according to Tables 2 and 3, there seems to be no relationship whatsoever between the "flexible margins" and the "cheaper hires".

Overall, Table 2 and Table 3 suggest that in the sample some margins were used as substitutes for other margins ("base-wage freezes" for "reduce employees" and for "cheaper hires", and "flexible margins" for "reduce employees"), but no significant evidence emerges as regards complementarity relationships. In the next section these relationships will be further characterised using an appropriate econometric model.

\section{Empirical Analysis}

\subsection{An econometric model for the cost-cutting strategies}

In the face of negative shocks firms are expected to respond through adjustments that affect directly their demand (price of the product) and/or their supply (costs of 
production). For reasons of data availability and econometric tractability, this paper focuses on the labour-cost adjustment strategies that Portuguese firms have used in the face of negative labour demand and supply shocks. Thus, implicitly, we assume that the degree of price stickiness and the costs of wage and employment adjustment determine the relative importance of the price versus the cost channel, but that the relationship among the different labour-cost margins is chiefly determined by their relative adjustment costs. This allows a two-stage approach where it is assumed that firms first decide whether to reduce prices and/or costs and then, conditional on having decided to reduce costs, they determine which type of costs they are going to cut, subject to technical or institutional restrictions. ${ }^{8}$

Against this background, we model firms' cost-cutting strategies by assuming the following multivariate recursive probit model:

$$
\begin{aligned}
& y_{i 1}^{*}=x_{i 1}^{\prime} \beta_{1}+\epsilon_{i 1} \\
& y_{i 2}^{*}=x_{i 2}^{\prime} \beta_{2}+\alpha_{1} y_{i 1}+\epsilon_{i 2} \\
& y_{i 3}^{*}=x_{i 3}^{\prime} \beta_{3}+\delta_{1} y_{i 1}+\delta_{2} y_{i 2}+\epsilon_{i 3} \\
& y_{i 4}^{*}=x_{i 4}^{\prime} \beta_{4}+\gamma_{1} y_{i 1}+\gamma_{2} y_{i 2}+\gamma_{3} y_{i 3}+\epsilon_{i 4}
\end{aligned}
$$

where $y_{i j}^{*}(\mathrm{i}=1, . . \mathrm{N} ; \mathrm{j}=1, \ldots 4)$ represents a latent variable which measures the amount of margin $j$ used by firm $i$ and $x_{i j}^{\prime}$ is a set of regressors whose impacts are measured by vector $\beta_{j}$. As $y_{i j}^{*}$ is not observed, we define, as usually:

$$
y_{i j}=1 \quad \text { if } \quad y_{i j}^{*}>0 ; \quad y_{i j}=0 \quad \text { if } \quad y_{i j}^{*} \leq 0, \quad i=1, . . N ; j=1, \ldots 4 .
$$

\footnotetext{
${ }^{8}$ Ideally, in order do draw conclusions on the impacts of the different regressors on the alternative adjustment channels, we would like to have detailed data on the reaction of firms to the different shocks. Our sample, has information on whether a given margin was used, but is mute on the frequency and timing of its utilisation. Thus, we proceed under the implicit identifying assumption that the data on the labour cost-cutting strategies is the result of a single reaction by the firm to a negative labour demand or labour supply shock (or a single reaction to the accumulation of several negative labour demand or supply shocks). This qualification requires, of course, that the estimated parameters be interpreted with some caution.
} 
Equations (8)-(11) describe the most general recursive triangular model that complies with the condition for logical consistency. It has been shown in the literature that such a model allows for causal interpretations enabling us to understand the underlying mechanisms generating the observations (see Maddala (1983)). It has also been shown that such a model does not suffer from identification problems. ${ }^{9}$

We define the 4 variables as follows: $y_{i 1}=$ "base-wage freezes", $y_{i 2}=$ "flexible margins", $y_{i 3}="$ cheaper hires" and $y_{i 4}=$ "reduce employees". By ordering "base-wage freezes" first, we are assuming that base wages are basically negotiated outside the firm, through collective agreements, such that they are not significantly affected by adjustments in the other cost margins, in line with a right-to-manage approach. In turn, by ordering "reduce employees" last, we are assuming that the probability of employment reduction may depend on whether the remaining margins are also used. Ceteris paribus, employment adjustment is expected to be lower when base wages are flexible and the firm has the possibility of using the "flexible margins" or the "cheaper-hires".

In model (8)-(11) it may further be assumed that:

$$
\operatorname{corr}\left(\epsilon_{i j}, \epsilon_{i k}\right)=\rho_{j k} \neq 0 \quad \forall j, k=1,2,3,4 \quad(j \neq k)
$$

Under assumption (13), the dependent variables $y_{i j}(\mathrm{j}=1,2,3)$ in the right-hand side of equations (9)-(11) are endogenous for the equations where they appear as regressors, and the full model (8)-(11) must be estimated using maximum likelihood methods. But if $\rho_{j k}=0, \quad \forall j, k \quad(j \neq k)$, the dependent variables $y_{i j}$ in the right-hand side of equations (9)-(11) become exogenous for estimation purposes and the model may be estimated using single equations methods.

Given that our purpose is to identify the relationships among the different costcutting strategies, model (8)-(11) is estimated by restricting the original sample to firms

\footnotetext{
${ }^{9}$ Wilde $(2000)$ has shown that the identification of the model is achieved if the same exogenous regressors appear in all equations, provided these regressors are sufficiently variable, so that theoretical identification does not require availability of additional instruments. See also Freedman and Sekhom (2010). Still, equations (8) and (9) in the estimated model include three additional regressors in order to ensure proper empirical identification of the model.
} 
that have reduced labour costs, i.e., that have used at least one cost-cutting strategy. Restricting the sample to firms that have reduced costs may raise sample selection issues because the restricted sample becomes endogenously determined. However, sample selection will only be a problem if the residuals in the selection equation are correlated with the residuals of the model estimated over the restricted sample. In order to handle this situation, we start by estimating model (8)-(11) together with a selection equation which, in our case, is an equation for the "cost margin" defined over the full sample:

$$
w_{i}^{*}=z_{i}^{\prime} \delta+v_{i}, \quad w_{i}=1\left[\left(w_{i}^{*}>1\right]\right.
$$

where $w_{i}=1$ if the firm has reduced costs (has used one cost margin at least), and $w_{i}=0$ otherwise; $z_{i}^{\prime}$ is a vector of exogenous regressors. From this model we may proceed by testing the joint hypothesis of endogeneity of the $y_{i j}$ variables $(\mathrm{j}=1,2,3)$ in equations (9)-(11) and the existence of sample selection problems, i.e.,:

$$
H_{0}: \rho_{j k}=\theta_{r}=0, \quad j, k, r=1,2,3,4 \quad(j \neq k)
$$

where $\theta_{r}=\operatorname{corr}\left(v_{i}, \epsilon_{i r}\right), r=1,2,3,4$.

According to the likelihood ratio (LR) test, the null hypothesis in equation (15) is not rejected at standard significance levels. More specifically, from the estimated model we get $\operatorname{LR}(10)=3.745$ with $\mathrm{P}$-value $=0.958$, so that the test suggests the absence of any significant correlation among the residuals of the recursive triangular model (8)-(11), as well as among those residuals and the residuals of the selection equation, suggesting that endogeneity and sample selection are not relevant issues in our case. ${ }^{10}$

It is well-known that inference on multivariate binary models is very demanding in terms of sample sizes (see, for instance, Fabbri et al. (2004)). Thus, we proceed by estimating the model using single equation methods as this is likely to imply strong

\footnotetext{
${ }^{10}$ The sample selection model is estimated by maximum likelihood methods using the mvprobit Stata routine with some modifications. Further details are available from the authors upon request.
} 
estimation efficiency gains. ${ }^{11}$

\subsection{Estimation results}

Table 4 presents the results of the estimated model and Table 5 reports the average direct marginal effects of each of the covariates on the probability of a firm using each labour cost-cutting strategy. ${ }^{12}$

The choice of the exogenous regressors, $x_{i j}$, to be used in the empirical model was guided by the literature on downward wage rigidity. These include regressors aimed at measuring the importance of workers' and firms' attributes such as tenure, the proportion of high-skilled blue- and white-collar workers, the proportion of permanent employees or of employees covered by collective wage agreements, the importance of competition, etc. The Appendix describes how they were constructed.

We start by investigating how the exogenous regressors affect the use of the labour cost-cutting strategies, and then proceed by analysing the relationships among these strategies, with a special focus on wage-freezes and employment.

\footnotetext{
${ }^{11}$ As a robustness check, we also conducted a single exogeneity test for the dependent variables $y_{i j}(\mathrm{j}=1,2,3)$ that appear as regressors in equations (9)-(11) by testing the correlation among the residuals of model (8)-(11). This hypothesis was tested using both the likelihood ratio (LR) test and the conditional moments $(\mathrm{CM})$ test. The first one requires estimating the full model by maximum likelihood methods, but the second one is particularly attractive as it is based on univariate probit estimation of the four equations. Simulations performed in Monfardini and Radice (2008) in a bivariate context show that the size of these two tests is not very sensitive to misspecification errors (omission of a relevant variable). For the two tests we get $\operatorname{LR}(6)=2.957$ with $\mathrm{P}$-value $=0.814$ and $\mathrm{CM}(6)=2.157$ with $\mathrm{P}$-value $=0.905$. Thus, both tests suggest the absence of any significant correlation involving the residuals of the recursive triangular model.

${ }^{12}$ The average marginal effects were calculated from the difference in the predicted probabilities conditional on marginal changes for continuous regressors and zero and one changes for discrete variables in each equation. We notice that in our triangular model the total marginal effect on $y_{j}$ from a covariate $x_{k}$ may be decomposed into the sum of a direct effect (the partial effect computed directly from the equation for $y_{j}$ ) and an indirect effect coming from the contribution of the equations that precede $y_{j}$ in the triangular model. For instance the impact of $x_{k}$ on the probability of "reduce employees" involves a direct effect through the "reduce employees" equation and an indirect effect from the use of the other margins: "base-wage freezes", "flexible margins" and "cheaper hires" (provided $x_{k}$ enters those equations as a regressor). Figures in Table 5 refer to the direct marginal effects, as in our case the indirect effects do not add a significant contribution to the total effect.
} 


\subsubsection{Effects of the exogenous regressors}

For ease of presentation, we grouped the exogenous regressors into the following four categories: 1) labour force composition, 2) union activity, 3) barriers to wage freezing and 4) other characteristics.

\section{Labour force composition}

This group includes the regressors that provide information about the labour force composition of the firm: proportion of workers with less than 5 years of tenure, the proportion of high-skilled blue- and white-collar workers, and the share of permanent employees.

According to the turnover model (Stiglitz (1974)), wages of high-tenured workers are expected to be more rigid downwards than those of low-tenured workers, but it may also be argued that high-tenured workers are more likely to face higher costs of job loss and thus might be expected to have lower bargaining power and thus lower degree of downward wage rigidity. ${ }^{13}$ Whether higher tenure is associated with higher or lower wage rigidity is therefore an empirical matter.

The results for this regressor indicate that it does not have a significant impact on the two compensation related margins, suggesting that it is not a relevant variable as regards firms' decisions on freezing base-wages or reducing the "flexible margins". In contrast, firms with a higher proportion of less experienced or younger workers are more likely to use the margin "cheaper hires". This result suggests that firms with a higher proportion of less experienced or younger workers are also the ones where quits are more frequent, allowing firms to reduce labour costs by paying lower wages to new employees. This result may be due to the prevailing dual labour market in Portugal which provides very high protection to older workers with open-ended contracts and very little to the

\footnotetext{
${ }^{13}$ If we consider the tenure profile of wages predicted by Lazear (1979), who suggests that workers are likely to earn less than the value of their marginal productivity (VMP) when they are young and to earn more than their VMPs when they are old, together with the shirking model (see Shapiro and Stiglitz (1984)), we conclude that the cost of job loss may be higher for older workers and workers with higher tenure. In fact, it is typically more difficult for older workers to find a new job and workers with long tenure often lose their tenure component of wages when changing jobs.
} 
younger ones with fixed-term contracts (see Centeno and Novo (2012)). In the case of "reduce employees", however, the coefficient is negative suggesting that firms with higher proportion of high-tenured workers are more likely to reduce employment in the face of negative shocks. This effect may stem from the fact that the proportion of high-tenured workers is proxying the age of the firm and collective dismissals being more frequent in older firms. ${ }^{14}$

The literature also suggests that wages of high-skilled or white-collar workers are likely to display higher downward rigidity than those of low-skilled or blue-collar workers either because the effort of high-skilled workers is more valuable and more difficult to monitor or because costs of hiring and training costs are higher for high-skilled and/or white-collar workers making firms more reluctant to cut their wages (see, for instance, Shapiro and Stiglitz (1984), Akerlof (1982) and Akerlof and Yellen (1990)).

From Tables 4 and 5, we see that, in comparison to low-skilled workers (blue- and white-collar), firms with more high-skilled workers are more likely to use the first three margins of adjustment: "base-wage freezes", "flexible margins" and "cheaper hires", but less likely to "reduce employees". These results, apparently not in line with most theories, are likely to reflect a greater use of flexible pay components among high-skilled workers. ${ }^{15}$

To the extent that workers with permanent contracts have more bargaining power in

\footnotetext{
${ }^{14}$ Tenure is usually seen as an endogenous variable in wage or dismissals equations defined at the worker level, where tenure endogeneity is due to unobserved worker's match and/or heterogeneity effects. However it is unclear whether one should expect tenure endogeneity to be an important issue for equations defined at the firm level and pertaining not to wage or unemployment levels equations, but to the probability of a firm freezing wages or reducing employment. Yet, to see whether tenure endogeneity could be a problem in our equation for "reduce employees" (tenure is not significant in the equations for "base-wage freezes" and "flexible margins"), we carried out a simple endogeneity test by estimating a bivariate probit model involving the equation for "reduced employees" (which includes tenure as a regressor) and an equation for tenure, but the test results clearly suggested the absence of any significant endogeneity problem.

${ }^{15}$ In practice, the sign and magnitude of the estimated parameters for some regressors, in the model for a given margin, are likely to depend not only on workers' relative bargaining power but also on how widespread that margin is across the different type of workers. For instance, the use of the "flexible margin" (bonus, benefits or promotions) is likely to be more widespread among the class of high-skilled and/or white-collar workers. Under these circumstances, firms with higher proportion of high-skilled and/or white-collar workers may emerge in the estimated models as displaying higher probability of reducing the flexible margin, in contrast to what the theory would suggest.
} 
the wage-setting process than workers with temporary contracts, the "insider-outsider model" (Lindbeck and Snower (1988)) will imply higher wage rigidity for the former group of workers. From Tables 4 and 5, we see that the impact of the share of permanent employees on each of the margins tends to be negative (the exception is "base-wage freezes"), even though not statistically significant for most of the margins. In line with the theory, this result suggests that the higher the share of permanent workers, the harder it is, in general, to use the adjustment margins.

Table 4: Labour cost-cutting strategies Probit estimates

\begin{tabular}{|c|c|c|c|c|}
\hline Regressors & $\begin{array}{c}\text { Base-wage } \\
\text { freezes }\end{array}$ & $\begin{array}{l}\text { Flexible } \\
\text { margins }\end{array}$ & $\begin{array}{c}\text { Cheaper } \\
\text { hires }\end{array}$ & $\begin{array}{c}\text { Reduce } \\
\text { employees }\end{array}$ \\
\hline constant & $\begin{array}{c}-0.6016^{* * *} \\
(0.2314) \\
\end{array}$ & $\begin{array}{c}-0.1915 \\
(0.2177)\end{array}$ & $\begin{array}{c}-1.1316^{* * *} \\
(0.1937)\end{array}$ & $\begin{array}{c}-1.3731^{* * * *} \\
(0.2108)\end{array}$ \\
\hline tenure less than 5 years & $\begin{array}{c}-0.2473 \\
(0.2335)\end{array}$ & $\begin{array}{l}0.0508 \\
(0.2088)\end{array}$ & $\begin{array}{c}0.4154^{*} \\
(0.2152)\end{array}$ & $\begin{array}{c}-0.7949^{* * *} \\
(0.2238)\end{array}$ \\
\hline high-skilled blue-collar & $\begin{array}{c}0.0055^{* * *} \\
(0.0019)\end{array}$ & $\begin{array}{c}0.0008 \\
(0.0017)\end{array}$ & $\begin{array}{c}0.0046^{* *} \\
(0.0018)\end{array}$ & $\begin{array}{c}-0.0035^{*} \\
(0.0020)\end{array}$ \\
\hline high-skilled white-collar & $\begin{array}{c}0.0055^{* *} \\
(0.0024)\end{array}$ & $\begin{array}{c}0.0040^{*} \\
(0.0022)\end{array}$ & $\begin{array}{c}0.0078^{* * *} \\
(0.0023)\end{array}$ & $\begin{array}{c}-0.0056^{* *} \\
(0.0025)\end{array}$ \\
\hline permanent employees & $\begin{array}{l}0.0962 \\
(0.1502) \\
\end{array}$ & $\begin{array}{c}-0.2458^{*} \\
(0.1416)\end{array}$ & $\begin{array}{c}-0.2261 \\
(0.1567) \\
\end{array}$ & $\begin{array}{c}-0.2113 \\
(0.1551)\end{array}$ \\
\hline coverage & $\begin{array}{c}-0.0098 \\
(0.1172)\end{array}$ & $\begin{array}{c}-0.0034 \\
(0.1070)\end{array}$ & $\begin{array}{c}0.0659 \\
(0.1120)\end{array}$ & $\begin{array}{c}0.3124^{* * *} \\
(0.1155)\end{array}$ \\
\hline legislation & $\begin{array}{c}-0.2068 \\
(0.1337)\end{array}$ & $\begin{array}{l}0.1273 \\
(0.1295)\end{array}$ & - & - \\
\hline reputation of the firm & $\begin{array}{c}-0.4832^{* * *} \\
(0.1163)\end{array}$ & $\begin{array}{c}-0.2184^{* *} \\
(0.1106)\end{array}$ & - & - \\
\hline workers attraction & $\begin{array}{l}0.1462 \\
(0.1180)\end{array}$ & $\begin{array}{c}-0.2179^{* *} \\
(0.1088)\end{array}$ & - & - \\
\hline openness & $\begin{array}{l}0.0396 \\
(0.1366)\end{array}$ & $\begin{array}{l}0.2594^{* *} \\
(0.1245)\end{array}$ & $\begin{array}{c}0.2596^{* *} \\
(0.1323)\end{array}$ & $\begin{array}{l}0.0739 \\
(0.1417)\end{array}$ \\
\hline size & $\begin{array}{c}-0.0499 \\
(0.1249)\end{array}$ & $\begin{array}{c}0.0218 \\
(0.1125)\end{array}$ & $\begin{array}{l}0.1498 \\
(0.1194)\end{array}$ & $\begin{array}{l}0.0570 \\
(0.1244)\end{array}$ \\
\hline services & $\begin{array}{l}0.1415 \\
(0.1328) \\
\end{array}$ & $\begin{array}{c}0.1052 \\
(0.1238) \\
\end{array}$ & $\begin{array}{c}-0.0453 \\
(0.1285) \\
\end{array}$ & $\begin{array}{l}0.0652 \\
(0.1336)\end{array}$ \\
\hline wage freezes & - & $\begin{array}{l}0.1554 \\
(0.1174)\end{array}$ & $\begin{array}{c}-0.3661^{* * *} \\
(0.1281)\end{array}$ & $\begin{array}{c}-0.6236^{* * *} \\
(0.1237)\end{array}$ \\
\hline flexible margins & - & - & $\begin{array}{l}0.0339 \\
(0.1077)\end{array}$ & $\begin{array}{c}-0.2122^{*} \\
(0.1097)\end{array}$ \\
\hline cheaper hires & - & - & - & $\begin{array}{c}-0.2097^{*} \\
(0.1207)\end{array}$ \\
\hline Number of observations & $\begin{array}{c}\chi_{(P=0.00)}^{2}=31.0 \\
\end{array}$ & $\begin{array}{c}\chi_{(P=0.01)}^{2}=26.4 \\
\end{array}$ & $\begin{array}{c}\chi_{(P=0.00)}^{2}=36.4 \\
\end{array}$ & $\begin{array}{c}\chi_{(P=0.00)}^{2}=61.2 \\
\end{array}$ \\
\hline $\mathrm{N}=635$ & $R^{2}=0.046$ & $R^{2}=0.031$ & $R^{2}=0.044$ & $R^{2}=0.080$ \\
\hline
\end{tabular}


Table 5: Labour cost-cutting strategies

Probit Model - Average marginal effects (direct effects)

\begin{tabular}{|c|c|c|c|c|}
\hline Regressors & $\begin{array}{l}\text { Base-wage } \\
\text { freezes }\end{array}$ & $\begin{array}{l}\text { Flexible } \\
\text { margins }\end{array}$ & $\begin{array}{c}\text { Cheaper } \\
\text { hires }\end{array}$ & $\begin{array}{c}\text { Reduce } \\
\text { employees }\end{array}$ \\
\hline tenure less than 5 years & $\begin{array}{c}-0.0761 \\
(0.0718)\end{array}$ & $\begin{array}{l}0.0195 \\
(0.0802) \\
\end{array}$ & $\begin{array}{c}0.1393^{*} \\
(0.0719)\end{array}$ & $\begin{array}{c}-0.2421^{* * * *} \\
(0.0663)\end{array}$ \\
\hline high-skilled blue-collar & $\begin{array}{c}0.0017^{* * *} \\
(0.0006)\end{array}$ & $\begin{array}{l}0.0003 \\
(0.0007)\end{array}$ & $\begin{array}{c}0.0016^{* *} \\
(0.0006)\end{array}$ & $\begin{array}{c}-0.0011^{*} \\
(0.0006)\end{array}$ \\
\hline high-skilled white-collar & $\begin{array}{c}0.0017^{* *} \\
(0.0007)\end{array}$ & $\begin{array}{c}0.0015^{*} \\
(0.0009)\end{array}$ & $\begin{array}{c}0.0026^{* * *} \\
(0.0007)\end{array}$ & $\begin{array}{c}-0.0017^{* *} \\
(0.0008)\end{array}$ \\
\hline permanent employees & $\begin{array}{c}0.0302 \\
(0.0480)\end{array}$ & $\begin{array}{c}-0.0937^{*} \\
(0.0530)\end{array}$ & $\begin{array}{c}-0.0733 \\
(0.0488)\end{array}$ & $\begin{array}{c}-0.0666 \\
(0.0503)\end{array}$ \\
\hline coverage & $\begin{array}{c}-0.0030 \\
(0.0361)\end{array}$ & $\begin{array}{c}-0.0013 \\
(0.0411)\end{array}$ & $\begin{array}{l}0.0221 \\
(0.0375)\end{array}$ & $\begin{array}{c}0.0968^{* * *} \\
(0.0359)\end{array}$ \\
\hline legislation & $\begin{array}{c}-0.0661 \\
(0.0440)\end{array}$ & $\begin{array}{l}0.0488 \\
(0.0493) \\
\end{array}$ & - & - \\
\hline reputation of the firm & $\begin{array}{c}-0.1539^{* * *} \\
(0.0372)\end{array}$ & $\begin{array}{c}-0.0847^{* *} \\
(0.0429)\end{array}$ & - & - \\
\hline workers attraction & $\begin{array}{c}0.0446 \\
(0.0356)\end{array}$ & $\begin{array}{c}-0.0843^{* *} \\
(0.0421)\end{array}$ & - & - \\
\hline openness & $\begin{array}{l}0.0123 \\
(0.0426)\end{array}$ & $\begin{array}{l}0.1000^{* *} \\
(0.0476)\end{array}$ & $\begin{array}{c}0.0897^{*} \\
(0.0467)\end{array}$ & $\begin{array}{l}0.0223 \\
(0.0423)\end{array}$ \\
\hline size & $\begin{array}{c}-0.0154 \\
(0.0386)\end{array}$ & $\begin{array}{l}0.0084 \\
(0.0432)\end{array}$ & $\begin{array}{l}0.0502 \\
(0.0398)\end{array}$ & $\begin{array}{l}0.0174 \\
(0.0381)\end{array}$ \\
\hline services & $\begin{array}{l}0.0444 \\
(0.0424) \\
\end{array}$ & $\begin{array}{l}0.0405 \\
(0.0477) \\
\end{array}$ & $\begin{array}{c}-0.0151 \\
(0.0426)\end{array}$ & $\begin{array}{l}0.0196 \\
(0.0399)\end{array}$ \\
\hline wage freezes & - & $\begin{array}{l}0.0600 \\
(0.0453)\end{array}$ & $\begin{array}{c}-0.1177^{* * *} \\
(0.0387)\end{array}$ & $\begin{array}{c}-0.2084^{* * * *} \\
(0.0432)\end{array}$ \\
\hline flexible margins & - & - & $\begin{array}{l}0.0114 \\
(0.0362)\end{array}$ & $\begin{array}{c}-0.0651^{*} \\
(0.0342)\end{array}$ \\
\hline cheaper hires & - & - & - & $\begin{array}{c}-0.0653^{*} \\
(0.0384)\end{array}$ \\
\hline
\end{tabular}

\section{Union activity}

The role played by labour unions in the wage setting process and the employment protection legislation is also likely to have strong implications for wage rigidity and for employment responses to shocks. The higher is the unions' bargaining power, the more rigid wages are expected to be and thus changes in employment are also likely to be higher. For instance, in the model developed in Holden (2004), downward wage rigidity is likely to be stronger the higher the coverage of collective agreements and the stricter the employment protection legislation. The idea is that with collective wage agreements wage cuts need the consent of employees and such cuts are more difficult to implement under stricter employment protection legislation. 
In order to capture the role played by unions in the wage setting process, we included the variables "coverage" and "legislation" in the model. The first measures the proportion of workers covered by collective agreements and the second is a dummy variable which equals one if the firm considers labour regulation or the collective wage agreement as a relevant or very relevant factor that prevents wages from being cut or frozen. ${ }^{16}$ From Tables 4 and 5, we see that the two regressors, with the exception of "reduce employees" are not very relevant to explain differences across firms in the use of the different cost-cutting strategies. In the case of coverage, we see that it increases the likelihood of a firm reducing employment, which suggests that the presence of unions does not limit the firms' ability to adjust the quantity margin.

\section{Barriers to wage freezing}

Efficiency wage theories and, in particular, the adverse selection model or the sociological models suggested in the literature may also explain why some firms do not freeze or cut wages in the event of negative shocks (see Katz (1986) and Campbell and Kamlani (1997)). According to these models, firms may be very reluctant to cut back wages or other compensation components if they think that would reduce workers effort and/or induce workers to shirk or to leave the firm, consequently increasing monitoring, supervising and/or turnover costs. In order to capture these ideas, we included in the model the variables "reputation of the firm" and "workers attraction". These are dummy variables which equal one if the firm considers that the negative consequences for the reputation of the firm and the difficulties in attracting new employees are relevant or very relevant factors that prevent cutting or freezing their nominal wages. We see from Tables 4 and 5 that the impact of these two regressors is negative both for "base-wage freezes" and "flexible margins", which means that these two obstacles to

\footnotetext{
${ }^{16}$ Notice that "legislation", "reputation of the firm" and "workers attraction" are included only in the first two equations. On the one hand, we believe that these regressors are capturing firm's characteristics that are expected to be more relevant for compensation related components and, on the other, by excluding them from the other two equations, we intend to ensure proper empirical identification of the model. See also footnote 9 .
} 
reducing or freezing base wages are also obstacles to reducing the flexible margins. ${ }^{17}$

\section{Other characteristics}

International economic integration is likely to increase both competition and factor substitutability, thus increasing the elasticity of labour demand and labour productivity (see Andersen et al. (2000)). Firms operating in such an environment should also feel stronger pressure to reduce costs and thus one may expect a more intense adjustment of wages and employment in reaction to shocks. But wage rigidity may also vary with firm size, as well as with the type of sector in which the firm operates. If monitoring costs and/or turnover costs are higher in larger firms (Oi (1983) and Barron et al. (1987)) such firms are more likely to pay efficiency wages in order to reduce the probability of shirking or to avoid the hiring and training costs and thus to exhibit stronger downward wage rigidity.

In order to account for these possibilities we included in the model the regressors openness, size and services. Openness measures the importance of exports for the firm (is a dummy variable that equals one if the share of exports on total sales is 50 percent or higher). From Tables 4 and 5, we see that firms where exports account for a higher share of total sales are also firms that adjust more their "flexible margins" and take advantage of existing "cheaper workers", in line with what could be expected.

From Tables 4 and 5, we conclude that large firms do not make more intensive use of the labour cost-cutting strategies than small firms. A similar conclusion holds for firms operating in the services sector.

\footnotetext{
${ }^{17}$ In this paper we assume that bonus and other monetary and non-monetary benefits are more flexible than base wages. This seems a reasonable hypothesis for countries like Portugal where base wages cannot be cut for legal reasons. However, in general, this is as debatable assumption. On the one hand, it may be argued that benefits over which the firm has at least some discretion are likely to be less rigid than wages because firms have more (and more subtle) ways to lower benefits than to lower wages. It has also been suggested that one of the reasons firms provide some benefits to employees is to reduce nominal wage rigidity (see Oyer (2005)). But, on the other hand, it may be claimed that many of the theories suggested in the literature to justify the presence of downward nominal wage rigidity are likely to apply to benefits too. In particular, efficiency wage theories would suggest that firms may be very reluctant to cut back bonus and other benefits for the reasons presented above. The estimated results for the covariates "reputation of the firm" and "workers attraction" show that this type of effect is indeed present in data. Thus, in general, whether bonus and benefits are significantly less rigid downwards than base wages is to be seen as an empirical matter.
} 


\subsubsection{Relationships among the labour-cost cutting strategies}

In general, we may expect the adjustment of a given margin to depend on the degree of rigidity of the other margins. For instance, the probability of a firm using employment adjustment as a reaction to a negative labour demand shock is expected to be higher when base wages are rigid and smaller if alternative more flexible margins are available.

We start by noticing that the estimated results in Tables 4 and 5 are consistent with the preliminary analysis presented in section 4. From the probit equation for "reduce employees", we see that "base-wage freezes", "flexible margins" and "cheaper hires" have been used as substitutes for employment reduction by Portuguese firms. In particular, from Table 5, we conclude that the probability of a firm reducing employment is around 21 percentage points lower for a firm that has frozen wages, and around 6.5 percentage points lower for a firm that has used the "flexible margins" or the "cheaper hires". ${ }^{18}$

The probability of a firm using "cheaper hires" is around 12 percentage points lower for a firm that has frozen wages. This result suggests that "cheaper hires" and "base-wage freezes" were used as substitutes by firms, i.e., "cheaper hires" were mainly used in situations in which firms were unable to freeze base wages following a negative labour demand shock or to compensate abnormal or unexpected base-wage increases following a negative labour supply shock.

In contrast, the "flexible margins" do not emerge as substitutes to "base-wage freezes". That would be the case if they had been mainly used to compensate for abnormal or unexpected base-wage increases. Rather, the relationship between these two margins is positive (even though not significantly so) which means that the "flexible margins" have been predominantly used as a complement to "base-wage freezes" in reaction to negative labour demand shocks.

\footnotetext{
${ }^{18}$ We notice, once again, that these are direct effects only, but that they do not significantly differ from the total effects. For instance, the total effect of "wage freezes" on "reduce employees" that takes into account the indirect effect through "cheaper hires" (the one that could be expected to differ the most from the direct effect) is around one percentage point less than the direct effect reported in Table 5 .
} 
The probability for a firm of reducing employment if it has frozen wages and used the "flexible margins" is around 29 percentage points lower than for an otherwise identical firm, and the probability for a firm of reducing employment if it has frozen wages and used the "flexible margins" and the "cheaper hires" is around 35 percentage points lower than for an otherwise identical firm. ${ }^{19}$

These results show that base-wage flexibility has a strong negative impact on the probability of a firm reducing employment, and that such effect has been significantly strengthened by the availability of alternative margins of labour cost adjustment, like the "flexible margins" and the "cheaper hires".

\section{Concluding remarks}

The studies aimed at assessing the extent and the effects of nominal wage rigidities have focused mainly on base wages or permanent wages (base wages plus the other components that are paid regularly on a monthly basis, such as meals allowances, tenurerelated components, etc.), leaving aside potentially more flexible pay-components such as performance related bonus and other monetary and non-monetary benefits which may strongly attenuate the negative impact on employment of base-wage rigidities.

Using survey data, this paper investigates the implications for employment of basewage rigidities together with other strategies that Portuguese firms have used to cut labour costs in the event of exogenous negative labour demand or supply shocks.

Our dataset shows that, among the firms that have reduced labour-costs, the reduction in the number of employees ("reduce employees") was by far the most commonly used strategy (around 72 percent of the firms) followed by the strategy "flexible margins", which includes the reduction or elimination of bonus payments and other monetary benefits, the reduction or elimination of non-monetary benefits and the slowdown

\footnotetext{
${ }^{19}$ These correspond to the following probabilities (not shown in Table 5):

$\operatorname{Prob}\left(y_{4}=1 \mid y_{1}=1, y_{2}=1, y_{3}, x_{4}\right)-\operatorname{Prob}\left(y_{4}=1 \mid y_{1}=0, y_{2}=0, y_{3}, x_{4}\right)$ and

$\operatorname{Prob}\left(y_{4}=1 \mid y_{1}=1, y_{2}=1, y_{3}=1, x_{4}\right)-\operatorname{Prob}\left(y_{4}=1 \mid y_{1}=0, y_{2}=0, y_{3}=0, x_{4}\right)$ respectively, where $y_{4}=$ reduce employees, $y_{3}=$ cheaper hires, $y_{2}=$ flexible margins, $y_{1}=$ wage freezes and $x_{4}=$ vector of exogenous regressors entering equation for $y_{4}$.
} 
or freezing of the rate at which promotions are filled (around 45 percent of the firms). The recruitment of new employees with a wage lower than the one of those who left the firm ("cheaper hires") was used by around 30 percent of the firms and around 26 percent of the firms have resorted to "base-wage freezes".

We find significant heterogeneity in the use of each of these strategies across firms. The use of each margin depends on several workers' and/or firms' attributes such as the tenure and skills distribution, measures of the unions' bargaining power, as well as some indicators of the economic environment in which firms operate. In particular, firms operating mainly in the foreign market, a more competitive environment, tend to use some of these strategies more heavily.

The econometric results suggest that the strategy "cheaper hires" is used as a substitute for "base-wage freezes" by Portuguese firms, i.e., it is predominantly used in situations in which firms do not freeze base wages after a negative labour demand shock or to compensate abnormal or unexpected base-wage increases after a negative labour supply shock. In contrast, the relationship between the strategies "flexible margins" and "base-wage freezes" is positive (even though not significantly so) which suggests that the "flexible margins" are predominantly used as a complement to "base-wage freezes" in reaction to negative labour demand shocks.

We also find a clear negative association between the margin "base-wage freezes", which we use as a measure of base-wage flexibility, and the strategy "reduce employees". In particular, we estimate that the probability of a firm reducing employment is around 21 percentage points lower for a firm that has frozen base wages than for an otherwise identical firm. The ability to use the "flexible margins" or "cheaper hires" also decreases the probability of a firm reducing employment (around 6.5 percentage points in each case). Together, the probability for a firm of reducing employment if it uses the strategies "base-wage freezes", "flexible margins" and "cheaper hires" is around 35 percentage points lower than for an otherwise identical firm.

Overall, we conclude that base-wage flexibility has a strong positive impact on 
employment, and that such positive impact has been significantly strengthened by the possibility of firms resorting to alternative margins of labour cost adjustment, like more flexible compensation components (bonus, benefits and promotions) and the recruitment of new employees at wages lower than those received by the employees that have left the firm. 


\section{Appendix - The covariates}

In this Appendix, we describe the covariates used in the probit models whose results are presented in section 4 , and provide the corresponding summary statistics. The details are as follows:

Tenure - Proportion of employees whose tenure is less than 5 years.

High-skilled blue-collar - Proportion of High-skilled blue-collar employees in total employment.

High-skilled white-collar - Proportion of High-skilled white-collar employees in total employment.

Permanent employees - Dummy variable that is equal to one if the proportion of permanent workers is higher than 98 percent of total workforce.

Coverage - Dummy variable that is equal to one if the proportion of employees covered by collective agreements is equal to eighty percent or higher.

Labour legislation - Dummy variable that equals one if the firm considers labour legislation or the collective agreement as an important or very important obstacle to freeze wages in a context where the firm needs to reduce costs.

Firm's reputation - Dummy variable that equals one if the firm considers that the negative impact on firm's reputation is an important or very important obstacle to freeze wages in a context where the firm needs to reduce costs.

Workers attraction - Dummy variable that equals one if the firm considers that the difficulties in attracting new employees is an important or very important obstacle to freeze wages in a context where the firm needs to reduce costs.

Openness-Dummy variable that equals one if the proportion of sales in the foreign market is 50 percent of total sales or higher.

Size - Equal to one if the number of employees is larger than 100.

Services - Equal to one if the firm operates in the Services sector. 


\section{References}

Akerlof, G. A. (1982), 'Labor contracts as partial gift exchange', Quarterly Journal of Economics 97(4), 543-569.

Akerlof, G. A., Dickens, W. R. and Perry, G. L. (1996), 'The macroeconomics of low inflation', Brookings Papers on Economic Activity 27(1), 1-76.

Akerlof, G. A. and Yellen, J. (1990), 'The fair wage-effort hypothesis and unemployment', Quarterly Journal of Economics 105(2), 255-283.

Altonji, J. G. and Devereux, P. J. (2000), 'The extent and consequences of downward nominal wage rigidity', in Worker Well-Being, 19, 383-431, Elsevier Science Inc.

Babecký, J., Caju, P. D., Kosma, D., Lawless, M., Messina, J. and Rõõm, T. (2009), The margins of labour cost adjustment: Survey evidence from European firms, Working Paper 1106, European Central Bank.

Babecký, J., Caju, P. D., Kosma, T., Lawless, M., Messina, J. and Rõõm, T. (2010), 'Downward nominal and real wage rigidity: Survey evidence from European firms', Scandinavian Journal of Economics 112(4), 884-910.

Barron, J. M., Black, D. A. and Loewenstein, M. A. (1987), 'Employer size: The implications for search, training, capital investment, starting wages, and wage growth', Journal of Labor Economics 5(1), 76-89.

Behr, A. and Pötter, U. (2010), 'Downward wage rigidity in europe: A new flexible parametric approach and empirical results', German Economic Review 11, 169-187.

Bertola, G. (1999), Microeconomic perspectives on aggregate labor markets, in O. Ashenfelter and D. Card, eds, 'Handbook of Labor Economics', Vol. 3 of Handbook of Labor Economics, Elsevier, chapter 45, pp. 2985-3028.

Campbell, Carl M, I. and Kamlani, K. S. (1997), 'The reasons for wage rigidity: Evidence from a survey of firms', The Quarterly Journal of Economics 112(3), 759-89. 
Carlsson, M. and Westermark, A. (2007), Optimal monetary policy under downward nominal wage rigidity, Working Paper Series 206, Sveriges Riksbank (Central Bank of Sweden).

Centeno, M. and Novo, A. A. (2012), Excess worker turnover and fixed-term contracts: Causal evidence in a two-tier system, Working Paper 5/2012, Banco de Portugal.

Dias, F., Esteves, P. and Félix, R. (2004), Revisiting the NAIRU estimates for the Portuguese economy, Economic Bulletin, Banco de Portugal.

Dickens, W. T., Goette, L., Groshen, E. L., Holden, S., Messina, J., Schweitzer, M. E., Turunen, J. and Ward, M. E. (2007), 'How wages change: Micro evidence from the International Wage Flexibility Project', Journal of Economic Perspectives 21(2), 195214 .

Dwyer, J. (2003), 'Nominal wage rigidity in australia', Australian Journal of Labour Economics (AJLE) 6(1), 5-24.

Elsby, M. W. (2009), 'Evaluating the economic significance of downward nominal wage rigidity', Journal of Monetary Economics 56(2), 154-169.

Fabbri, D., Monfardini, C. and Radice, R. (2004), Testing exogeneity in the bivariate probit model: Monte Carlo evidence and an application to health economics, Working Paper 514, Dipartimento Scienze Economiche, Universitá di Bologna.

Fehr, E. and Goette, L. (2005), 'Robustness and real consequences of nominal wage rigidity', Journal of Monetary Economics 52(4), 779-804.

Freedman, D. A. and Sekhom, J. S. (2010), 'Endogeneity in probit response models', Political Analysis 18(2), 138-150.

Gaspar, V. and Luz, S. (1997), Wages and unemployment in Portugal, Economic Bulletin, Banco de Portugal. 
Goette, L., Sunde, U. and Bauer, T. (2007), 'Wage rigidity: Measurement, causes and consequences', Economic Journal 117(524), F499-F507.

Gordon, R. J. (1996), 'Comment and discussion: Akerlof et al.: the macroeconomics of low inflation', Brookings Papers on Economic Activity 1, 66-78.

Hamermesh, D. S. (1987), The demand for labor in the long run, in O. Ashenfelter and R. Layard, eds, 'Handbook of Labor Economics', Vol. 1 of Handbook of Labor Economics, Elsevier, chapter 8, pp. 429-471.

Holden, S. (2004), 'The costs of price stability: Downward nominal wage rigidity in Europe', Economica 71, 183-208.

Holden, S. and Wulfsberg, F. (2008), 'Downward nominal wage rigidity in the OECD', The B.E. Journal of Macroeconomics 8(1), (Advances), Article 15.

Holden, S. and Wulfsberg, F. (2009), 'How strong is the macroeconomic case for downward real wage rigidity?', Journal of Monetary Economics 56(4), 605-615.

Katz, L. F. (1986), 'Efficiency wage theories: A partial evaluation', in NBER Macroeconomics Annual 1986, pp. 235-289, S. Fisher (ed.), Cambridge, Mass: MIT Press.

Knoppik, C. and Beissinger, T. (2006), Downward nominal wage rigidity in Europe: An analysis of European micro data from the ECHP 1994-2001, Working Paper 275, Universät Hohenheim, Stuttgart.

Lazear, E. P. (1979), 'Why is there mandatory retirement?', Journal of Political Economy 87(6), 1261-1284.

Lebow, D. E., Saks, R. E. and Wilson, B. A. (2003), 'Downward nominal wage rigidity: Evidence from the employment cost index', The B.E. Journal of Macroeconomics 3(1), (Advances), Article 2.

Lindbeck, A. and Snower, D. J. (1988), The insider-outsider theory of employment and unemployment, MIT Press, Cambridge, MA. 
Luz, S. and Pinheiro, M. (1993), Unemployment, vacancies and wage growth, Economic Bulletin, Banco de Portugal.

Maddala, G. S. (1983), Limited-Dependent and Qualitative Variables in Econometrics, Cambridge University Press.

Mankiw, N. G. (1996), 'Comment and discussion: Akerlof et al.: the macroeconomics of low inflation', Brookings Papers on Economic Activity 1, 66-78.

Marques, C. R. (2008), Wage and price dynamics in Portugal, Working Paper Series 945, European Central Bank.

Martins, F. (2011), Price and wage setting in Portugal: Learning by asking, Working Paper Series 1314, European Central Bank.

Messina, J., Duarte, C. F., Izquierdo, M., Caju, P. D. and Hansen, N. L. (2010), 'The incidence of nominal and real wage rigidity: An individual-based sectoral approach', Journal of the European Economic Association 8(2-3), 487-496.

Messina, J. and Sanz-de Galdeano, A. (2011), Wage rigidity and disinflation in emerging countries, IZA Discussion Papers 5778, Institute for the Study of Labor (IZA).

Monfardini, C. and Radice, R. (2008), 'Testing exogeneity in the bivariate probit model: A Monte Carlo study', Oxford Bulletin of Economics and Statistics 70(2), 271-282.

OECD (1992), OECD Economic Surveys: Portugal 1991/92, Organization for Economic Co-operation and Development, Paris.

Oi, W. Y. (1983), 'The fixed employment costs of specialized labor', in The measurement of labor cost, pp. 63-122, Chap. 2, J. Triplett (ed.), University of Chicago Press, Chicago.

Oyer, P. (2005), Can employee benefits ease the effects of nominal wage rigidity?: Evidence from labor negotiations, Working paper, Graduate School of Business, Stanford University. 
Portugal, P., Carneiro, A. and Guimarães, P. (2010), On the cyclical sensitivity of real wages, Economic bulletin, Banco de Portugal.

Radowski, D. and Bonin, H. (2008), Sectoral differences in wage freezes and wage cuts: evidence from a new firm survey, Discussion Paper Series 1: Economic Studies 24/2008, Deutsche Bundesbank, Research Centre.

Shapiro, C. and Stiglitz, J. E. (1984), 'Equilibrium unemployment as a worker discipline device', American Economic Review 74(3), 433-44.

Stüber, H. and Beissinger, T. (2012), 'Does downward nominal wage rigidity dampen wage increases?', European Economic Review (forthcoming).

Stiglitz, J. E. (1974), 'Alternative theories of wage determination and unemployment in LDC's: The labor turnover model', Quarterly Journal of Economics 88(2), 194-227.

Topel, R. H. (1986), 'Local labor markets', Journal of Political Economy 94(3), S111S143.

Venn, D. (2009), Legislation, collective bargaining and enforcement: Updating the OECD employment protection indicators, OECD Social, Employment and Migration Working Paper 89, OECD.

Wilde, J. (2000), 'Identification of multiple equation probit models with endogenous dummy regressors', Economics Letters 69(3), 309-312. 